\title{
RANCANGAN MODEL MEDIA AUDIO PERMAINAN DAN CERITA ANAK NUSANTARA (PERMATA NUSANTARA) UNTUK PAUD
}

\author{
Suparti \\ Balai Pengembangan Media Radio Pendidikan dan Kebudayaan \\ Kementerian Pendidikan dan Kebudayaan \\ suparti@kemdikbud.go.id
}

\begin{abstract}
Abstrak
Salah satu prinsip pembelajaran di PAUD adalah belajar melalui bermain. Berbagai aspek perkembangan anak dapat ditingkatkan melalui kegiatan permainan, misalnya permainan tradisional. Namun, berbagai permainan tradisonal mulai tergantikan dengan permainan modern yang bersifat pasif. Penelitian ini merupakan jenis penelitian kualitatif yang bertujuan merancang sebuah model media audio Permata Nusantara (Permainan dan Cerita Anak Nusantara) yang dikembangkan dengan mengadopsi model ADDIE yang daapt dimanfaatkan untuk mendukung pembelajaran di PAUD. Rangkaian kegiatan ini merupakan sebuah tindak lanjut terhadap hasil evaluasi model MA Permata Nusantara yang direvisi berdasarkan hasil evaluasi yang dikembangkan sebelumnya. Penelitian ini dilakukan pada bulan Maret dan April 2016 dengan melibatkan praktisi lapangan atau guru TK/PAUD sebanyak 12 orang, ahli materi yaitu dosen PAUD sebanyak 2 orang, dan ahli media dari BPMRPK sebanyak 6 orang. Hasil penelitian ini berupa blue print atau cetak biru model media audio Permata Nusantara yang meliputi spesifikasi model, rancangan garis besar isi media (GBIM), dan rancangan pengembangan bahan belajar. Dengan adanya cetak biru yang baik, diharapkan produk model media yang dihasilkan akan lebih baik.
\end{abstract}

Kata Kunci: desain, media audio, permata nusantara, PAUD

\section{DESIGNING THE MODEL OF GAMES AND STORY CHILDREN (PERMATA NUSANTARA) AUDIO MEDIA FOR EARLY CHILDHOOD EDUCTION}

\begin{abstract}
One of the learning principles in early childhood is learning through play. Various aspects of child development can be enhanced through game activities, such as traditional games. However, a variety of traditional games is being replaced with a modern game that makes children being passive. This study was a qualitative research with the goal of designing an audio media model, named Permata Nusantara (Permainan dan Cerita Anak Nusantara) which was developed by adopting the ADDIE model. The design of audio media model was a follow-up of the results of audio media evaluation which was done previously. This study was conducted in March and April 2016 and involved 12 kindergarten teachers, 2 content experts, and 6 media experts from BPMRPK. The results of this research was a blueprint of audio media model, including the specification, the outline of media content (GBIM), and the design of learning materials. A good blueprint was expected to yield good products.
\end{abstract}

Keywords: design, audio media, Permata Nusantara

\section{PENDAHULUAN}

Anak-anak identik dengan dunia bermain. Melalui bermain, anak-anak dapat meningkatkan keterampilan, dan kemampuan mereka dalam banyak hal. Bermain sendiri merupakan suatu kegiatan 
yang dapat dilakukan dengan atau pun tanpa alat. Dengan bermain, anak-anak akan mendapatkan rasa senang. Imajinasi mereka pun akan meningkat, begitu juga dengan kreatifitas dan kemampuan fisik mereka (Nurmayani, 2014:1). Jadi, melalui bermain, bukan hanya kemampuan fisik motorik anak saja yang berkembang, namun juga perkembangan agama dan moral, kemampuan kognitif, kecerdasan sosial emosional, bahkan kemampuan seni pun akan berkembang. Selain itu, berbagai permainan yang dilakukan anak akan mempengaruhi pertumbuhan fisik, mental dan jiwa anak di masa dewasa kelak. Anak akan terbentuk apakah akan memiliki fisik yang kuat atau kah lemah, memiliki mental dan jiwa yang baik ataukah buruk. Menjadi pribadi yang jujur atau pun curang, tangguh atau cengeng, berjiwa sportif atau pengecut banyak dipengaruhi oleh perkembangan di masa anak-anak. (Cholimah, Nur: 2016).

Ada berbagai macam permainan yang dapat digunakan untuk meningkatkan kreativitas dan kemampuan anak usia dini, salah satunya yaitu permainan tradisional. Pada hakikatnya, permainan tradisional merupakan hasil warisan budaya bangsa yang mengandung nilai-nilai pendidikan dan sesuai dengan dunia anak dalam rangka mengasah kemampuan mereka untuk berfantasi, berkreasi, berolah raga, melatih ketangkasan, sekaligus sarana untuk melatih kehidupan bermasyarakat bila waktunya tiba (Andriani: 2012: 122).

Namun, dunia bermain anak, khususnya yang berkaitan dengan permainan tradisional, kini mulai tergeser oleh permainan-permainan modern yang berbasis teknologi digital dan cenderung membuat anak menjadi pasif . Unsur-unsur permainan dengan basis budaya daerah pun banyak ditinggalkan. Berangkat dari keprihatinan tersebut, Balai Pengembangan Media Radio Pendidikan dan Kebudayaan (BPMRPK), yang merupakan sebuah institusi di bawah Kementerian Pendidikan dan Kebudayaan berusaha untuk mengembangkan sebuah model media yang dapat membantu mengatasi keprihatinan tersebut. Salah satu model yang dikembangkan adalah Media Audio Permata Nusantara (Permainan Tradisional Anak Nusantara). Permata Nusantara yang merupakan model media yang terdiri atas cerita dramatisasi permainan, belajar menyanyikan lagu permainan, serta kegiatan permainan itu sendiri yang dilakukan setelah pemanfaatan media audio dengan disertai petunjuk pemanfaatan program untuk guru. Dalam prosedur pengembangannya, salah satu model yang diadopsi BPMRPK adalah ADDIE model, yaitu sebuah tahapan prosedur pengembangan yang terdiri dari 5 tahapan/proses yang merupakan sebuah siklus yaitu: Analyis, Design, Development, Implementation, Evaluation. Pada tahap analisis, persoalan pembelajaran diklarifikasi, tujuan pembelajaran ditetapkan, lingkungan belajar, pengetahuan serta ketrampilan pun diidentifikasi. Pada tahap desain, blue print dan rancangan program dibuat dan ditindaklanjuti dengan tahap pengembangan yang dalam konteks ini meliputi penulisan naskah dan bahan penyerta serta produksi media lengkap dengan evaluasi produk dan revisinya. Produk yang telah dihasilkan selanjutnya diimplementasikan di lapangan untuk mendapatkan umpan balik dan selanjutnya dievaluasi untukmendapatkan

rekomendasi mengenai produk/model media audio yang telah dikembangkan. Evaluasi dalam konteks ini merupakan evaluasi sumatif yang berkaitan dengan kebijakan dan keberlanjutan program sedangkan evaluasi yang bertujuan untuk memperbaiki sebuah produk atau evalusi formatif dapat dilakukan pada tiap tahap pengembangannya.

Berangkat dari hasil evaluasi terhadap model media audio Permata Nusantara yang menyatakan bahwa media ini sangat layak dimanfaatkan sebagai suplemen atau media pendukung pembelajaran di PAUD, ada beberapa rekomendasi terhadap MA Permata Nusantara jika akan 
dikembangkan pada tahapan berikutnya. Beberapa catatan tersebut antara lain menyangkut 1) pengubahan format sajian media; 2) durasi cerita dramatisasi yang perlu diperpendek menjadi sekitar 7-10 menit; 3) pengubahan nama tokoh utama karena di daerah tertentu, nama tokoh yang memiliki konotasi negatif di daerah tertentu; 4) perlunya menasionalisasi permainan tradisional dengan memodifikasi permainan yang masih bersifat kedaerahan menjadi jenis permainan yang bisa diterima secara umum serta; 5) serta perlunya menyederhanakan lembar evaluasi agar bisa sederhana dan tidak merepotkan (Suparti, dkk.: 2015).

Pada penelitian sebelumnya tentang metode permainan tradisional untuk pembelajaran di PAUD pernah dilakukan di TK ABA Rejodani, Sleman, Yogyakarta menunjukkan bahwa berbagai permainan tradisional yang diajarkan terbukti dapat meningkatkan kemampuan anak dalam berhitung, berfikir fokus, mudah bergaul, berkomunikasi, bersosialisasi dan menjalin kerjasama (Ulfatun, 2014: viii). Ini berarti bahwa pembelajaran dengan memanfaatkan permainan tradisional dapat meningkatkan aspek kemampuan kognitif dan sosial emosional anak. Selain itu, permainan tradisonal juga dapat digunakan untuk meningkatkan kemampuan fisik motorik anak sebagaimana penelitian yang dilakukan di R.A Khoiriyatus Sibyan, Tuban (Effendi, 2015:11).

Berdasarkan permasalah dan hasil evaluasi terhadap model MA Permata Nusantara, ada salah satu tahapan dalam prosedur pengembangan model media audio yang harus dibenahi karena berimbas pada tahapan kegiatan/proses berikutnya. Tahapan yang dimaksud yaitu menyangkut desain /blue print dari model media audio Permata Nusantara dengan versi baru yang diperbaiki berdasarkan hasil evaluasi. Proses penyusunan desain program/media ini terwadahi dalam rangkaian kegiatan lokakarya Penyusunan Garis Besar Isi Media (GBIM) dan Jabaran
Materi (JM) dengan melibatkan unsur utama antara lain: praktisi lapangan, ahli materi dan pembelajaran, serta ahli media. Oleh karena itu, penelitian ini bertujuan untuk menghasilkan sebuah desain model media audio Permainan dan Cerita Anak Nusantara untuk Pendidikan Anak Usia Dini (PAUD). Hasil yang diperoleh dalam kegiatan ini selanjutnya akan dijadikan panduan dalam penulisan naskah dan bahan penyerta pada rangkaian tahapan kegiatan berikutnya.

\section{Model Pengembangan Media}

Ada berbagai model dalam prosedur pengembangan media atau program pembelajaranmisalnya model ASSURE dengan 6 tahapan prosesnya yaitu: Analyze Learners, State Objective, Select Media and Materials, Utilize Media and Materials, Require Learner Participation, Evaluate and Revise - Analisis Pebelajar, Menentukan Tujuan, Memilih Media dan Materi, Memanfaatkan Media dan Materi, Mengembangkan Peran Serta Pebelajar, Mengevaluasi dan Merevisi (Smaldino, 2005). Selain itu ada model Dick dan Carey dengan unsurnya yaitu: identifikasi tujuan pembelajaran, melakukan analisa pembelajaran, menganalisis karakteristik siswa dan konteks pembelajaran, merumuskan tujuan performasi, mengembangkan butir-butir tes acuan patokan, mengembangkan strategi pembelajaran, mengembangkan dan memilih bahan ajar, merancang dan melakukan evaluasi formatif, melakukan revisi terhadap program pembelajaran, serta merancang dan mengembangkan evaluasi sumatif (Dick dan Carey, 2005).

Salah satu model yang diadaptasi oleh BPMRPK dalam pengembangan media audio pembelajaran adalah model ADDIE: Analyze, Design, Develop, Implement, Evaluate atau Analisis, Desain, Pengembangan, Pemanfaatan, dan Evaluasi (McGriff, 2000:1). Dalam konteks pengembangan model media audio pembelajaran, analisis adalah sebuah proses untuk mendefinisikan apa yang 
perlu dipelajari, apa yang dibutuhkan, dan bagaimanakah karakteristik dari target sasaran. Sementara desain adalah proses merancang blue print atau cetak biru dari model yang dikembangkan, seperti apakah spesifikasinya, bagaimanakah pesan/materi pembelajaran tersebut akan disampaikan. Pengembangan adalah sebuah proses untuk memproduksi materi pembelajaran sesuai dengan blue print yang telah ditetapkan. Sementara Implementasi adalah sebuah proses untuk menentukan kelayakan dari model yang telah dikembangkan setelah program tersebut dimanfaatkan. Evaluasi adalah proses untuk menentukan keakuratan dan kelayakan dari model yang dikembangkan yang hasilnya digunakan untuk membuat keputusan apakah akan ditindaklanjuti ataukah dihentikan. Reiser and Dempsey, 2002:12), (McGriff, 2011).

\section{Pengembangan Desain Media Audio Pembelajaran}

Untuk mengembangkan sebuah model media audio pembelajaran, rancangan atau desain yang merupakan sebuah cetak biru atau blue print dari model yang akan dikembangkan sangat diperlukan. Ibarat sebuah bangunan, gambar rancang bangun atau blue print sangat diperlukan sebelum bangunan tersebut dibuat. Ada beberapa komponen yang diperlukan sebelum sebuah program atau media dikembangkan. Beberapa di antaranya yaitu: menentukan tujuan pengembangan model, menentukan spesifikasi produk, menentukan format Garis Besar Isi Media (GBIM) dan Jabaran Materi 9JM) yang memuat tujuan pembelajaran, merumuskan materi pembelajaran, merumuskan evaluasi atau alat pengukur keberhasilan, menentukan garis besar program media.

\section{Garis Besar Isi Media (GBIM) dan Jabaran Materi (JM)}

Kegiatan penyusunan GBIM dan JM didahului dengan kegiatan pemetaan kompetensi untuk mentukan apakah sebuah topik atau bahasan cocok untuk diaudiokan. Dalam memetakan kompetensi media pembelajaran, acuan yang digunakan salah satunya adalah kurikulum yang berlaku pada jenjang dan tingkat satuan pendidikan yang telah ditetapkan. Proses pemetaan penting karena belum tentu semua materi pembelajaran cocok untuk disampaikan melalui media audio. Oleh karena itu, telaah topik sangat diperlukan untuk membantu tahap pengembangan selanjutnya. Segera setelah GBIM selesai dibuat, yang perlu dilakukan selanjutnya adalah penyusunan Jabaran Materi atau JM yang merupakan rancangan pengembangan bahan belajar. JM diperlukan untuk memudahkan penulis naskah menyampaikan gagasannya. Selain itu, JM juga dibuat dengan alasan belum tentu penulis naskah media audio terlibat dalam penyusunan GBIM JM. Dengan adanya GBIM JM, penulis naskah akan mempunyai gambaran dan acuan mengenai materi yang akan disampaikan pada naskah audionya terutama jika penulis naskah bukan orang yang ahli atau menguasai materi pembelajaran atau pun bidang studi yang akan ditulis. Oleh karena itu, kebenaran dan kejelasan materi sangat diperlukan sebgai dasar pada pengembangan naskah dan juga produksinya.

Dalam media audio yang bersifat pembelajaran atau instruksional, penyusunan GBIM dan JM melibatkan berbagai unsur antara lain penulis GBIM JM, pengkaji/ahli materi, dan pengkaji/ahli media. Penulis merupakan praktisi dan pengembang instruksional di bidangnya. Sementara itu, pengkaji materi adalah ahli yang bertanggung jawab terhadap kebenaran dan kelayakan materi terhadap media yang akan dikembangkan sedangkan pengkaji media adalah orang yang bertanggung jawab terhadap estetika dan kelayakan media audio yang akan dikembangkan.

Pengembangan GBIM JM sangat diperlukan khususnya dalam pengembangan media audio pembelajaran karena beberapa alasan antara lain: untuk meminimalkan kesalahan materi, 
menghindari penyimpangan dari tujuan yang telah ditetapkan, mengantisipasi kelemahan dan kekurangan agar bisa diantipasi dan direvisi serta untuk menjaga standarisasi atau kualitas media yang akan dibuat.

\section{METODE}

Penelitian ini merupakan jenis penelitian pengembangan pada tahapan desain atau rancangan produk model media yang dilaksanakan pada bulan Maret dan April 2016. Penelitian ini bersifat kualitatif dan melibatkan responden yaitu 18 guru TK/PAUD di Yogyakarta, 2 orang ahli materi dan pembelajaran dari UNY dan 1 orang ahli materi dan pembelajaran dari STIE Bina Insani Yogyakarta, dan 9 orang ahli media dari BPMRPK. Instrumen yang dipakai dalam penelitian ini adalah panduan wawancara yang dilaksanakan melaui diskusi terfokus dan studi dokumen. Kerangka berpikir dalam desain atau rancangan pengembangan model media audio pembelajaran ini adalah sebagai berikut. Sampel penelitian diambil dengan tenik purposive sampling yaitu teknik pengambilan data dengan pertimbangan mewakili kelompok guru TK/PAUD sebagai praktisi dilapangan, dosen PAUD sebagai ahli materi dan pembelajaran dan karyawan BPMRPK sebagai ahli media.

Adapun alur dalam desain atau pengembangan rancangan produk model media audio Permata Nusantara digambarkan sebagai berikut.

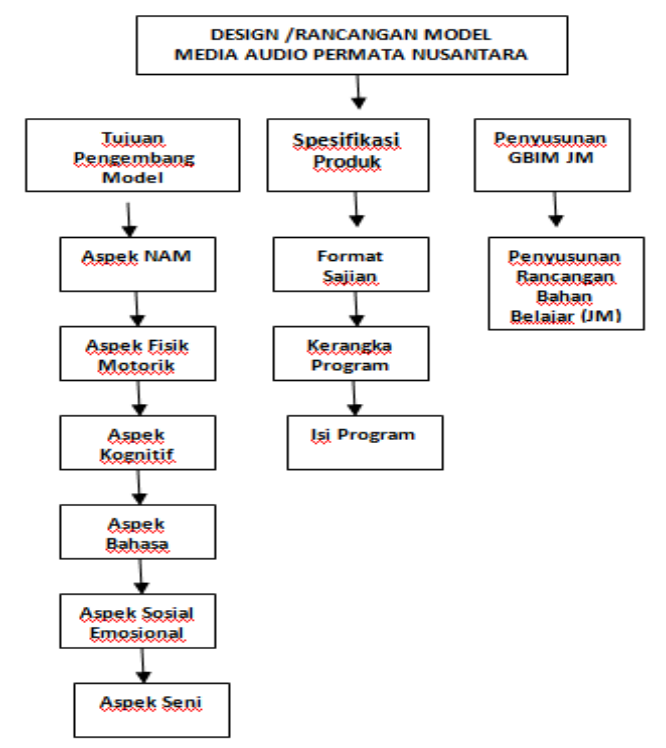

Gambar 1. Kerangka berpikir Pengembangan Rancangan Produk Media Audio Permata Nusantara

Dari kerangka berpikir yang ditunjukkan pada gambar 1, terlihat bahwa hal pertama yang dilakukan dalam pengembangan rancangan produk adalah menentukan tujuan pengembangan model, yaitu untuk membantu meningkatkan aspek perkembangan anak yang meliputi nilai agama dan moral (NAM), fisik motorik, kognitif, bahasa, sosial emosional, dan seni anak. Selanjutnya ditentukan juga spesifikasi produk dengan berdasar pada hasil analisis kebutuhan di lapangan yang meliputi format sajian, kerangka dan isi program. Selain itu juga format GBIM dan $\mathrm{JM}$ atau rancangan pengembangan bahan belajar.

\section{HASIL DAN PEMBAHASAN Tujuan Pengembangan Model}

Model media audio Permata Nusantara adalah model media audio pembelajaran cerita dan permainan anak nusantara yang dilengkapi bahan penyerta berupa Panduan Pemanfaatan untuk Guru. Model media audio ini dapat dimanfaatkan untuk mengembangkan aspek agama dan moral (NAM), fisik motorik, kognitif, bahasa, sosial emosional, dan seni anak. 


\section{Format Sajian, Kerangka, dan Isi Program}

Media audio Permata Nusantara dapat disajikan dengan media handphone dan MP3/MP4 Player serta komputer/laptop dengan software Winamp dan Windows Media Player. Berikut adalah tampilan kerangka dan isi program.

Tabel 1.Spesifikasi Fisik Program

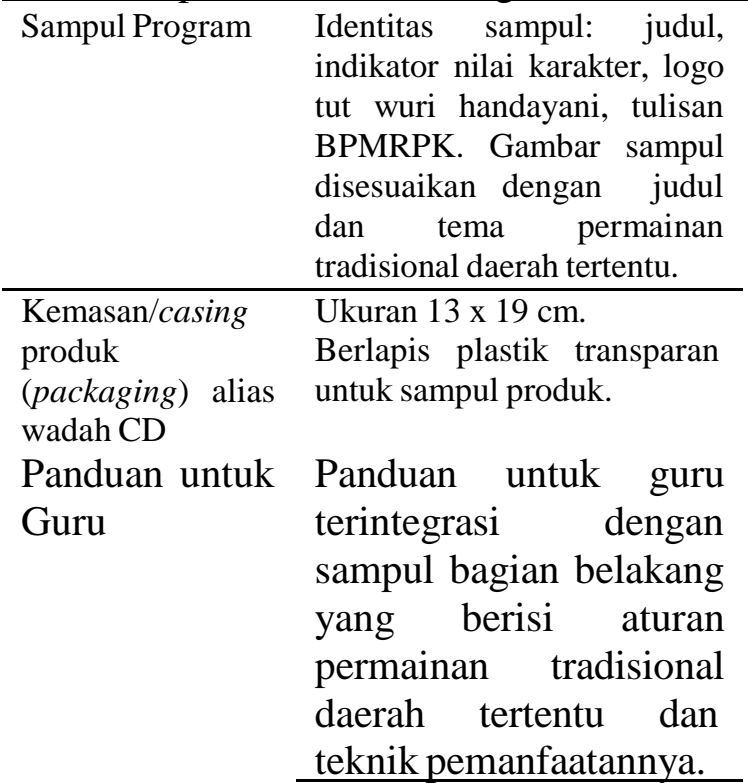

Tabel 2.Spesifikasi Isi Program

\begin{tabular}{ll}
\hline Materi Program & Asal daerah permainan \\
& tradisional. \\
& Peralatan yang dibutuhkan. \\
& Peserta permainan. \\
& Tempat dan waktu permainan. \\
& Persiapan sebelum permainan \\
& dilakukan. \\
& Aturan permainan. \\
& Tata cara permainan (tahapan \\
& dalam melakukan permainan). \\
& Aspek-aspek \\
& dikembangkan. \\
& Nilai-nilai/ aspek apa saja yang \\
& bisa dikembangkan dari \\
& permainan. \\
& Track 1 berisi dramatisasi cerita \\
& permainan yang diperankan oleh \\
& Pino dan Tata. Tujuannya untuk \\
& memberi gambaran permainan \\
Kemediaan & secara utuh dan mengenalkan \\
& budaya asal usul permainan. \\
& Track 2 berisi cara mengajarkan \\
& lagu yang ada dalam permainan \\
& (khusus untuk permainan \\
& dengan lagu). Tujuannya untuk \\
& membantu guru dalam \\
mengajarkan lagu yang terdapat & dalam permainan. \\
Track 3 berisi instrument
\end{tabular}

pengiring lagu dalam permainan (khusus untuk permainan dengan lagu). Tujuannya untuk mengiringi anak-anak dalam menyanyikan lagu permainan. Panduan Guru berisi petunjuk pemanfaatan sebelum, selama, dan s telah pemanfaatan media audio Permata Nusantara, baik untuk Track 1, 2, dan 3 serta panduan praktik bermain.

\section{Komponen-komponen dalam GBIM dan JM Media Audio Permata Nusantara}

\section{Komponen GBIM}

Setelah proses pemetaan kompetensi inti dan kompetensi dasar sesuai kurikulum 2013 untuk PAUD, tahapan selanjutnya adalah penyusunan GBIM dan JM. Penyusunan GBIM JM melibatkan unsur penulis, ahli materi, dan ahli media.

Secara umum, ada beberapa komponen utama yang diperlukan dalam penyusunan GBIM untuk PAUD yaitu: 1) identifikasi program/media (tema, judul, format rancangan, sasaran, penulis, pengkaji materi, pengkaji media, sasaran, dsb.) 2) tabel yang memuat tentang Kompetensi Inti, Kompetensi Dasar, Lingkup Perkembangan, Standar Tingkat Pencapaian Perkembangan Anak, Pokokpokok Materi, Judul, Evaluasi, serta Refernsi atau Acuan.

Tabel 3 berikut merupakan bagian identifikasi dari format GBIM PAUD model Permata Nusantara. Bagian identifikasi terdiri atas: 1) Nama Program yaitu Permata Nusantara; 2) Kode Program yang berisi nomor program, tahun pembuatan serta judul program; 3) Kategori Permainan dalam konteks ini adalah permainan dengan lagu; 4) Kompetensi Inti sesuai Kurikulum PAUD 2013; 5) Kompetensi Dasar sesuai Kurikulum PAUD 2013; 6) Indikator Perkembangan; 7) Judul Permainan; 8) Asal Permainan yang merupakan asal usul daerah permainan yang mendasari modifikasi permainan yang akan dibuat; 9) Pokok-pokok materi; 10) Tema yang merupakan alat yang akan digunakan 
untuk mengenalkan cerita dan permainan dalam Permata Nusantara dan mengaitkannya dengan Kurikulum 2013;

11) sasaran diisi dengan kelompok umur 4-5 tahun (TK A), umur 5-6 tahun (TK B), ataukah bisa digunakan di keduanya; 12) Penulis, Pengkaji Materi, dan Pengkaji Media merupakan komponen SDM yang terlibat dalam kegiatan penyusunan GBIM Permata Nusantara.

Tabel 3. Format GBIM Permata Nusantara

\begin{tabular}{|c|c|c|}
\hline Nama Program & $\vdots$ & Permata Nusantara \\
\hline Kode Program & $:$ & $\begin{array}{l}\text { PN. NO. TAHUN. NAMA } \\
\text { PERMAINAN }\end{array}$ \\
\hline Kategori & : & Permainan dengan Lagu \\
\hline Permainan & & \\
\hline Kompetensi Inti & : & \\
\hline Kompetensi & : & \\
\hline Dasar & & \\
\hline Indikator & $:$ & \\
\hline Perkembangan & & \\
\hline Judul Permainan & : & \\
\hline Asal Permainan & $:$ & \\
\hline Tema & : & \\
\hline Pokok-pokok & $:$ & \\
\hline Materi & & \\
\hline Sasaran & : & \\
\hline Durasi Audio & : & Track $1 \ldots .$. \\
\hline & & Track $2 \ldots \ldots$ \\
\hline & & Track $3 \ldots \ldots$. \\
\hline Penulis & $:$ & \\
\hline Pengkaji Materi & : & \\
\hline Pengkaji Media & : & \\
\hline Produksi & & Kementerian \\
\hline & & Pendidikan d \\
\hline
\end{tabular}

Sementara Tabel 4 berikut merupakan bagian identifikasi dari format JM PAUD model Permata Nusantara yang meliputi bagian identifikasi yang senada dengan bagian identifikasi pada format GBIM dilanjutkan uraian materi yang memuat dramatisasi cerita permainan dan cara melakukan permainan. Selain itu juga memuat petunjuk bagaimana memanfaatkan media audio Permata Nusantara dan melakukan praktik permainan, baik sebelum, selama, dan setelah pemanfaatan media.

Tabel 4. Format Jabaran Materi (JM)

\begin{tabular}{llll}
\hline Nama Program & $:$ & Permata Nusantara & \\
Kode Program & $:$ & PN. NO. TAHUN. NAMA \\
& PERMAINAN & \\
Kategori & $:$ & Permainan dengan Lagu \\
Permainan & &
\end{tabular}

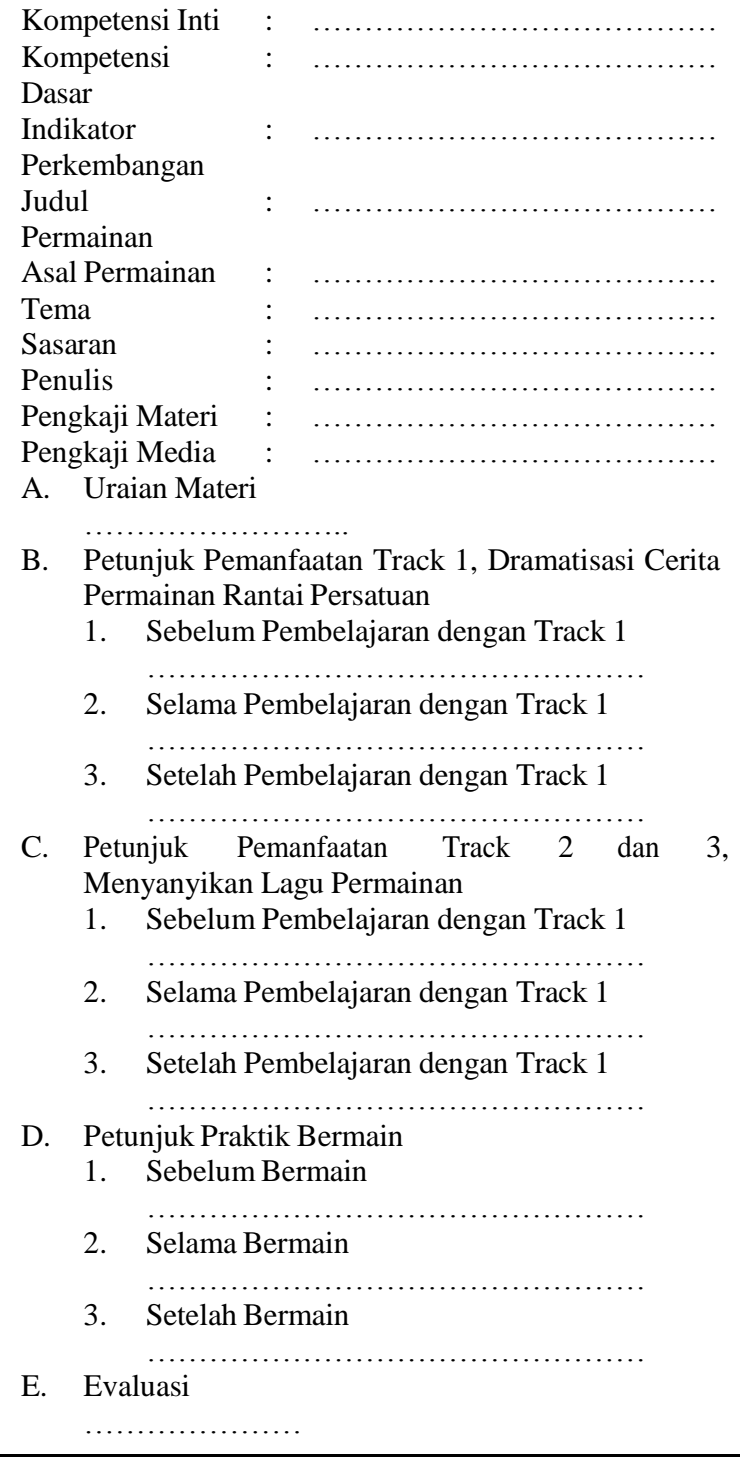

Format GBIM JM ini selanjutnya akan digunakan sebagai dasar dalam menyusun GBIM dan JM/rancangan pengembangan bahan belajar. Di tahun 2016, BPMRPK mengembangkan 30 GBIM JM media audio Permata Nusantara. Berikut daftar judul GBIM JM Permata Nusantara yang dikembangkan BPMRPK:

Tabel 5. Nama dan Tema Permainan

\begin{tabular}{clrl}
\hline No & \multicolumn{2}{c}{ Nama permainan } & \multicolumn{1}{c}{ Tema } \\
\hline 1. & $\begin{array}{l}\text { Permainan } \\
\text { citaku“ }\end{array}$ & "Cita- & Pekerjaan \\
2. & $\begin{array}{l}\text { Permainan "Lompat- } \\
\text { lompatan" }\end{array}$ & Binatang \\
3. & $\begin{array}{l}\text { Permainan } \\
\text { Aku" }\end{array}$ & "Tebak & Tanaman \\
4. & $\begin{array}{l}\text { Permainan "Nyamuk" } \\
\text { 5. }\end{array}$ & $\begin{array}{l}\text { Kebutuhanku } \\
\text { Permainan "Ibu Tuti" }\end{array}$ & Pekerjaan
\end{tabular}




\begin{tabular}{|c|c|c|c|}
\hline 6. & $\begin{array}{l}\text { Permainan } \\
\text { Tangan" }\end{array}$ & “Sapu & Kebutuhanku \\
\hline 7. & Permainan "Sia & iapa Aku" & Binatang \\
\hline 8. & $\begin{array}{l}\text { Permainan } \\
\text { Persatuan" }\end{array}$ & "Rantai & Negaraku \\
\hline 9. & Permainan "Do & omikado" & Tubuhku \\
\hline 10. & $\begin{array}{l}\text { Permainan "Po } \\
\text { Bolong" }\end{array}$ & Pong-pong & Tanaman \\
\hline 11. & $\begin{array}{l}\text { Permainan } \\
\text { Ting-tong" }\end{array}$ & "Bethet & Diri Sendiri \\
\hline 12. & Permainan "Ku & ubuk" & Tanaman \\
\hline 13. & $\begin{array}{l}\text { Permainan } \\
\text { Lompat" }\end{array}$ & "Pat & Binatang \\
\hline 14. & $\begin{array}{l}\text { Permainan } \\
\text { Tangan" }\end{array}$ & “Telapak & $\begin{array}{l}\text { Anggota } \\
\text { Tubuh }\end{array}$ \\
\hline 15. & $\begin{array}{l}\text { Permainan } \\
\text { Bintang" }\end{array}$ & "Bulan & Alam Sekitar \\
\hline 16. & $\begin{array}{l}\text { Permainan } \\
\text { Serimpang" }\end{array}$ & "Jahe & Tanaman \\
\hline 17. & $\begin{array}{l}\text { Permainan } \\
\text { ampar Pisang" }\end{array}$ & "Ampar- & Tanaman \\
\hline 18. & $\begin{array}{l}\text { Permainan } \\
\text { Bimbi” }\end{array}$ & "Cuk-cuk & Diri Sendiri \\
\hline 19. & $\begin{array}{l}\text { Permainan } \\
\text { megoak" }\end{array}$ & "Megoak- & Binatang \\
\hline 20. & $\begin{array}{l}\text { Permainan } \\
\text { Cirip it" }\end{array}$ & "Cing & $\begin{array}{l}\text { Anggota } \\
\text { Tubuh }\end{array}$ \\
\hline
\end{tabular}

Hasil dari penyusunan GBIM JM ini selanjutnya akan digunakan sebagai pedoman dalam kegiatan selanjutnya, yaitu proses pengembangan yang meliputi penulisan naskah dan bahan penyerta serta proses produksi media audio Permata Nusantara.

\section{PENUTUP}

Rancangan produk media audio Permata Nusantara merupakan sebuah desain atau blue print yang akan menjadi dasar dalam pengembangan produk media audio pembelajaran permainan dan cerita anak nusantara yang dilengkapi dengan bahan penyerta. Model media audio ini akan dikemas dalam format audio mp3 yang terdiri atas 3 track yaitu: 1) Track 1 yang berisi dramatisasi cerita dan permainan; 2) Track 2 yang berisi materi belajar menyanyikan lagu permainan; dan 3) Track 3 yang berisi instrumetalia lagu permainan yang dapat digunakan sebagai media karaoke. Kemasan produk ini akan ditampilkan dalam bentuk CD audio yang dilengkapi dengan sampul program yang memuat cover gambar tema sampul, identifikasi program, dan deskripsi program. CD audio ini dilengkapi dengan buku yang merupakan panduan pemanfaatan media audio Permata Nusantara.

Selain rancangan spesifiaksi produk, desain rancangan ini juga menghasilkan format GBIM JM yang secara umum memuat identifikasi, tujuan pengembangan model, kompetensi inti, kompetensi dasar, tema, nama permainan, uraian materi, dan panduan pemanfaatan. Setelah dipetakan, ada 30 judul permainan yang akan dikembangkan dengan dibungkus oleh tema pembelajaran yang sesuai.

Secara umum, hasil rancangan produk model media audio Permata Nusantara ini bermanfaat sebagai dasar dalam tahapan pengembangan selanjutnya, yaitu proses penulisan naskah dan bahan penyerta.

\section{UCAPAN TERIMA KASIH}

Penulis menyadari bahwa artikel ini dapat diselesaikan atas dukungan dan bantuan dari berbagai pihak. Oleh karena itu, penulis mengucapkan terima kasih kepada semua pihak yang telah memberikan kontribusi dalam penyelesaian artikel ini. Secara khusus, ucapan terima kasih disampaikan kepada Ibu Nur Hayati, M.Pd. dan Ibu Nur Cholimah, S.Pd., M. Pd. Atas bimbingan dan kerjasamanya selama ini.

\section{DAFTAR PUSTAKA}

Andriani, T. (2012). Permainan Tradisional Dalam Membentuk Karakter Anak Usia Dini. Jurnal Sosial Budaya Vol. 9 No. 1 Januari - Juli 2012.

Dick W., Carey, L. (1990). The Systematic Design of Instruction. New York: Harper Collins Publishers. 
Efendi, I. D. (2015). Permainan Tradisional sebagai Media Stimulasi Aspek Perkembangan Fisik Motorik Anak Usia Dini. Didaktika, Vol. 13 No. 3 Desember 2015.

Hill, M.G. (2015).

Children Understanding the

World through Play.

Retrieved from

http://www.educationinnovations. org/research-and-

evidence/children-understandingworld-through-play. Diakses 15 Maret 2016.

McGriff, S. (2011). The ADDIE Model: Designing, Evaluating

Instructional Coach Effectiveness. Retrieved from www.asq.org/.../the-addie-modeldesigning-evaluatinginstructional-coacheffecti...2011American Society for Quality. Diakses 12 Maret 2017.

Nurmayani. (2014). Bermain dan Kreatifitas pada Anak Usia Dini. Jurnal Pengabdian kepada Masyarakat LPM, Vol.20, No.77, Tahun XX, September 2014.

Cholimah, N. (2016). Diskusi dalam Kegiatan Lokakarya Penyusunan GBIM JM Permata Nusantara di Hotel Fave Yogyakarta.

Reiser, R., Dempsey, J. (2002). Trends and Issues in Instructional Design and Technology. New Jersey: Pearson Education, Inc.

Suparti, dkk. (2015). Evaluasi Model Media Audio Permainan Tradisional Anak Nusantara. Yogyakarta: BPMRP.
Smaldino, S dkk. (2005). Instructional Technology and Media for Learning. New Jersey: Pearson Prentice Hall.

Ulfatun, S. (2014). Pelaksanaan Permainan Tradisional dalam Meningkatkan kecerdasan Emosi Anak di TK ABA Rejodani, Sariharjo, Ngaglik, Sleman. Yogyakarta: Fakultas Ilmu Tarbiyah dan Keguruan, Universitas Sunan Kalijaga, Yogyakarta. 